\title{
First report on Biological Evaluation and Preliminary Screening of Fungal Endophytes from Spilanthes paniculata, a Medicinal Herb in Arunachal Pradesh, India
}

\author{
Richa Sharma, Sumpam Tangjang* and Tonlong Wangpan \\ Department of Botany, Rajiv Gandhi University, Rono Hills, Doimukh-791112, \\ Arunachal Pradesh, India \\ *Corresponding author
}

\begin{tabular}{|l|}
\hline K e y w o r d s \\
$\begin{array}{l}\text { Endophytes, Fungi, } \\
\text { Medicinal plant, } \\
\text { Pharmaceutical products }\end{array}$ \\
\hline Article Info \\
\hline $\begin{array}{l}\text { Accepted: } \\
12 \text { October } 2018 \\
\text { Available Online: } \\
10 \text { November } 2018\end{array}$ \\
\hline
\end{tabular}

\section{Introduction}

Endophytes are microbes, belonging to ascomycetes and anamorphic fungi (Arnold, 2007). Fungal endophytesliving, internal tissues of plants without causing any mistreat to their host (Bacon and White, 2000). Mostly, they represent an important quantifiable component of fungal biodiversity (Krings et al., 2007). Endophytic fungi benefits the
Endophytes are important source of natural bioactive products because these fungal endophytes are able to take unique biological and ecological niches and grow in nonordinary environments. Many natural bioactive compounds produced by medicinal plants are reportedly produced by their fungal endophytes. Spilanthes paniculata (locally called Marsang in Arunachal Pradesh) is known to possess medicinal properties. In the present study, the endophytic mycoflora of $S$. paniculata was studied. In order to isolate fungal endophytes, 150 segments (50 leaf, 50 stem, and 50 root samples) of 15 different plants of S. paniculata were screened. Finally, 110 isolates consisting of twenty different fungal genera, out of which, seven belonged to the class Ascomycetes, twelve (Deuteromycetes) and one (Ulvophycetes). Among the parts studied, the highest species richness as well as frequency of colonization was reported in Leaf. Overall, colonization frequency was determined $73.33 \%$ of surface sterilized tissue. Colletotrichum was found to be the most dominant endophytic species followed by Fusarium, Manokwaria and Oncopodium. It is worth mentioning that the genera Pestalotiopsis, Drecheslra, Cylindrocladium, Aspergillus, Nodulisporium were, first reported from Arunachal Pradesh. The present study was therefore, initiated to study the endophytic fungal population in S. paniculata, a commonly used medicinal plant in Arunachal Pradesh, northeast India. 
defense (Arnold, 2003). Further, these microbes produce a plethora of bioactive metabolites of unique structure, benzopyranones, flavonoids, phenolic acids, steroids, tetralones, xanthones (Tan and Zou, 2001) of potentially immense value in agriculture, industry and medicine (Selim, 2012). Medicinal plants have been known haven for fungal endophytes because they are able to produce bioactive compounds similar to those of their host (Zhang, 2006; Khan, 2010). The universality of these symbiotic fungal endophytes is clear, but host range, variety and geographical distribution have been unknown (Arnold and Engelbrecht, 2007). Thus, only a few numbers of medicinal plants have been studied for their fungal endophyte biodiversity and the potential to produce secondary bioactive metabolites (Khan, 2007).

Arunachal Pradesh also known as the "Paradise of Botanists" is known to have more than 500 species of medicinal plants (Tag et al., 2005). S. paniculata belongs to Asteraceae family with a long history of medicinal application is widely used in conventional and modern Medicine, which are known to harbour endophytic fungi that are believed to be associated with the production of pharmaceutical products (Zhang, 2006). The pharmaceutical properties of this plant can be attributed to its endophytes and there appears to be different endophytes with bioeffects. This research was to isolate and identify the endophytic fungi of $S$. paniculata in Arunachal Pradesh.

\section{Materials and Methods}

\section{Study area and sample collection}

The state of Arunachal Pradesh (29 $30^{\prime} \mathrm{N}$; $97^{\circ} 30^{\prime} \mathrm{E}$ ) is recognized as the $25^{\text {th }}$ biodiversity hotspot in the world (Chowdhery, 1999) and among the 200 globally important ecoregions
(Olson and Dinerstein, 1998). S. paniculata was collected from Botanical Garden, Rajiv Gandhi University, Papum Pare District of Arunachal Pradesh (Fig. 1 and 2). The plant material was brought to the laboratory in sterile bags and processed within hours after sampling.

\section{Surface sterilization and incubation}

Isolation of fungal endophytes was done according to the method described by Petrini et al., (1986). These medicinal plant samples were washed gently in running tap water to remove soil and debris. Leaf samples were cut into $0.5 \mathrm{~cm}^{2}$ pieces while, stems and roots samples were cut into $0.5-1.0 \mathrm{~cm}$. The pieces were then surface-sterilized by dipping them serially in $70 \%$ ethanol for 5 second and in $4 \%$ $\mathrm{NaOCl}$ for 90 second and were finally rinsed in sterile distilled water for 10 second (Suryanarayanan et al., 1998). Of these, only 150 segments were selected randomly and plated on Potato Dextrose Agar (PDA) medium (supplemented with $150 \mathrm{mg} / \mathrm{L}$ chloramphenicol) contained in Petridishes and were observed for the growth of endophytes. Each $9 \mathrm{~cm}$ diameter Petridish had $20 \mathrm{~mL}$ medium and was plated with 10 leaf segments. Petridishes were incubated under near ultraviolet lamps (12 h dark: $12 \mathrm{~h}$ light cycle) for 25 days at $28^{\circ} \mathrm{C}$, as this treatment was given for induce sporulation in fungi (Suryanarayanan et al., 2015). Colonization Frequency (CF) was calculated as described by Suryanarayanan et al., (2003).

CF of endophyte $=\frac{\text { Number of segments colonized by fungi }}{\text { Total number of segment observed }} \times 100$

For identification, fungi were grown on specified culture media under specified culture condition and identified on the basis of their morphological and cultural characteristics (Domsch et al., 1980; Ellis, 1971; Kenneth et 
al., 1965; Sutton, 1980).

\section{Results and Discussion}

The present study is the first report about the endophytic flora of $S$. paniculata, a medicinal plant found in this region. A total of 150 segments including 50 leaf, 50 stem and 50 root segments were screened for the presence of endophytic fungi (Table 2; Fig. 4 and 5). Finally, 110 isolates consisting of twenty different fungal genera, out of which, seven belonged to the class Ascomycetes, twelve (Deuteromycetes) and one (Ulvophycetes). The microscopic pictures of these fungi are depicted in Figure 3. It includes eleven fungi from leaves, nine from stems and seven from roots (Table 1). The observation shows that highest species richness and frequency of colonization, was recorded in leaf followed by stem and root.

In the present study, Colletotrichum sp. was found to be the most dominant endophytic species which is not organ-specific. It has been isolated from leaf, stem and root tissues in three replicates. Further, Colletotrichum spp., Cladosporium spp., Chaetomiun spp. were common in all the plant parts; however, Xylaria was isolated from stem and roots, and Aspergillus could be isolated from leaves and roots, respectively. Among the identified isolates, the most abundant genera were Colletotrichum, Fusarium, Manokwaria and Oncopodium. The genera Pestalotiopsis, Drecheslra, Cylindrocladium, Aspergillus, Nodulisporium were also, first time reported for the first time in this study. Overall, colonization frequency was determined $73.33 \%$ of surface sterilized tissues.

Endophytic organisms have received considerable attention as they are found to protect their host against pest, pathogens and even domestic herbivorous (Weber, 1981). Only a few plants have been investigated for their endophytic flora and their potential to produce bioactive compounds. Some studies have been conducted about the endophytic biodiversity, taxonomy, reproduction, host ecology and their effects on host (Redman et al., 2002, Domsch et al., 1980; Dayle et al., 2001; Clay and Schardl 2002). Currently, endophytes are considered as unexplored source of bioactive natural compounds. They have been found to play a crucial role in the production of beneficial chemical compounds. Taxol, an antifungal and anticancer compound, is one such example. It was found to be a product of endophytic fungi that colonizes on Taxus brevifolia and other plants (Gangadevi and Muthumary, 2007; Strobel et al., 1996).

The biodiversity of endophytic fungi of medicinal plants are completely overlooked aspect of plant biology of Arunachal Pradesh. The present work was initiated to find out endophytic fungal population in widely used medicinal plant, $S$. paniculata. Various fungal endophytes population was detected to colonize this plant. Twenty fungal genera were isolated. The highest species richness, as well as frequency of colonization was found in leaves. Cladosporium sp., however, was found in both leaf and stem, while Xylaria, was isolated from roots and stems. In this study, most dominant endophyte was found to be Colletotrichum. Overall colonization frequency was determined as $73.33 \%$ in surface sterilized tissues.

In most of the cases, Ascomycetes, Deuteromycetes and Basidiomycetes are reported as endophytic fungi (Petrini, 1986; Clay and Schardl, 2002). A large number of genera and species of fungi, belonging to first two classes, are able to live endophytically in plants. In the present study, the isolated fungi belonged to the class Ascomycetes and Deuteromycetes. 
Table.1 Endophytic fungi isolated from different parts of Spilanthes paniculata

\begin{tabular}{|c|c|c|c|}
\hline S. No. & Site of Isolation & Number of Sample & Number of Fungi Isolated \\
\hline 1. & Leaf & 50 & 11 \\
\hline 2. & Stem & 50 & 9 \\
\hline 3. & Root & 50 & 7 \\
\hline & Total number of isolates & 150 & 27 \\
\hline
\end{tabular}

Table.2 Name and colonizing frequency of Endophytic fungi isolated from S. paniculata

\begin{tabular}{|c|c|c|c|c|c|c|}
\hline S. & Name of Endophytic & \multicolumn{3}{|c|}{ Isolated From } & Frequency (\%) of & No. of \\
\hline 1 & Colletotrichum & Leaf & Stem & Root & $33.33 \%$ & 17 \\
\hline 2 & Oncopodium & Leaf & - & - & $16 \%$ & 8 \\
\hline 3 & Nodulisporium & Leaf & - & - & $10 \%$ & 5 \\
\hline 4 & Cylindrocladium & Leaf & - & - & $4 \%$ & 2 \\
\hline 5 & Fusarium & Leaf & - & - & $20 \%$ & 10 \\
\hline 6 & Cladosporium & Leaf & Stem & - & $14 \%$ & 7 \\
\hline 7 & Aspergillus & Leaf & - & Root & $14 \%$ & 7 \\
\hline 8 & Taeniolellea & Leaf & - & - & $2 \%$ & 1 \\
\hline 9 & Nigrospora & Leaf & - & - & $14 \%$ & 7 \\
\hline 10 & Phaeotrichoconis & Leaf & - & - & $4 \%$ & 2 \\
\hline 11 & Chaetomium & Leaf & Stem & - & $12 \%$ & 6 \\
\hline 12 & Corynespora & - & Stem & - & $6 \%$ & 3 \\
\hline 13 & Lasiodiplodia & - & Stem & - & $2 \%$ & 1 \\
\hline 14 & Dreschslera & - & Stem & - & $2 \%$ & 1 \\
\hline 15 & Alterneria & - & Stem & - & $10 \%$ & 5 \\
\hline 16 & Xylaria & - & Stem & Root & $12 \%$ & 6 \\
\hline 17 & Pestalotiopsis & - & Stem & - & $12 \%$ & 6 \\
\hline 18 & Phomopsis & - & - & Root & $8 \%$ & 4 \\
\hline 19 & Penicillium & - & - & Root & $6 \%$ & 3 \\
\hline 20 & Manokwaria & - & - & Root & $18 \%$ & 9 \\
\hline
\end{tabular}


Fig.1 Sample collection site of Spilanthes paniculata in Arunachal Pradesh, India (Red circle indicates collection site)
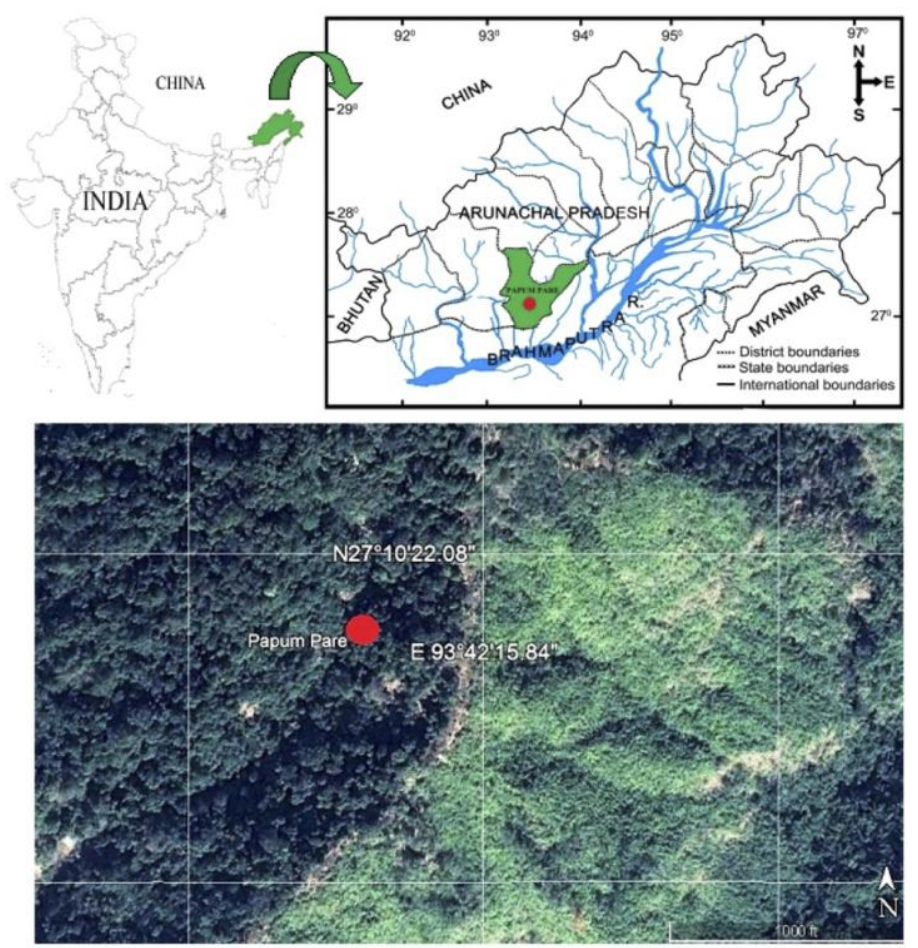

Fig.2 Image of $S$. paniculata (Wall. ex DC.) medicinal plant

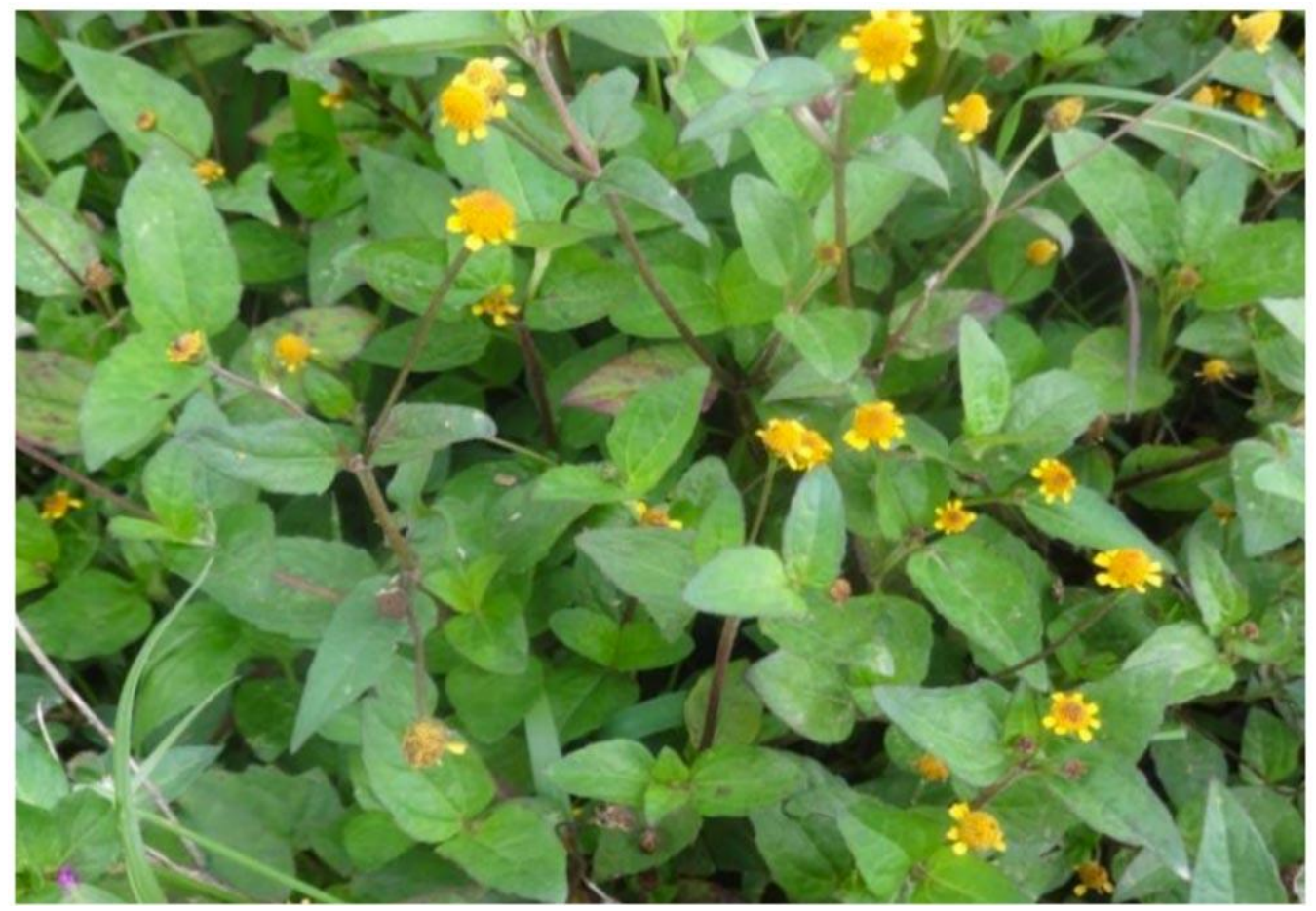


Fig.3 Endophytic fungi isolated from the different parts of $S$. paniculata
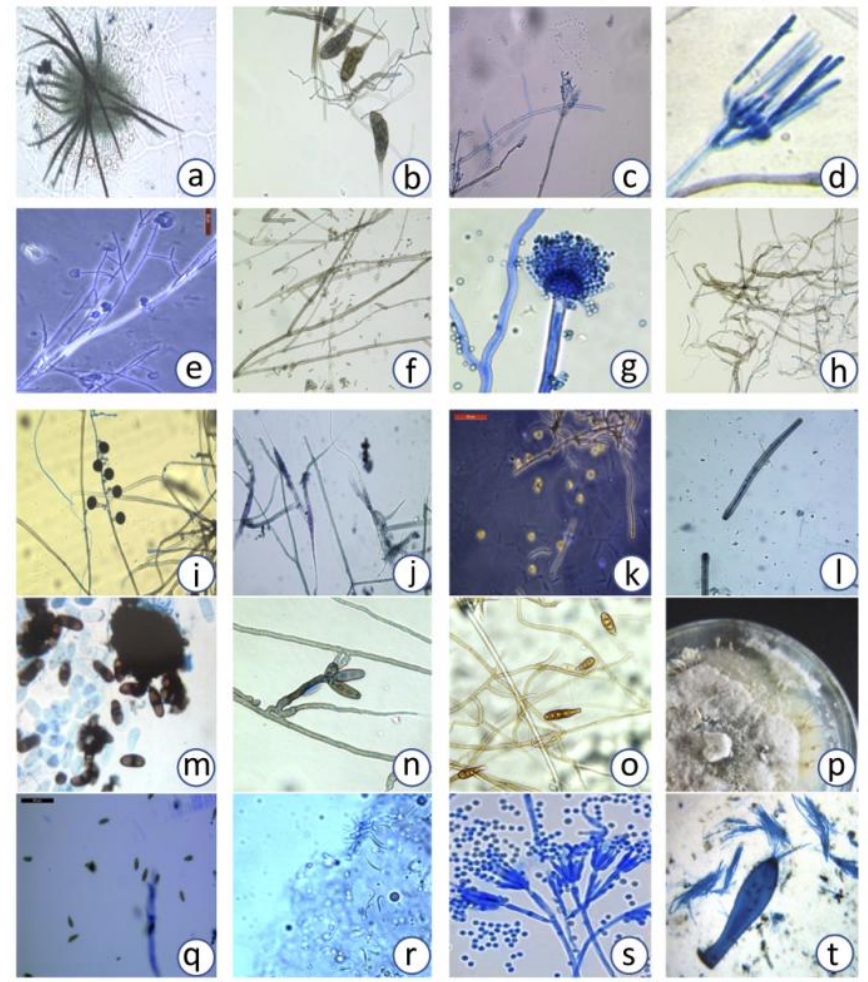

Fig.4 Endophytic fungi (\%) isolated from different parts of S. paniculata

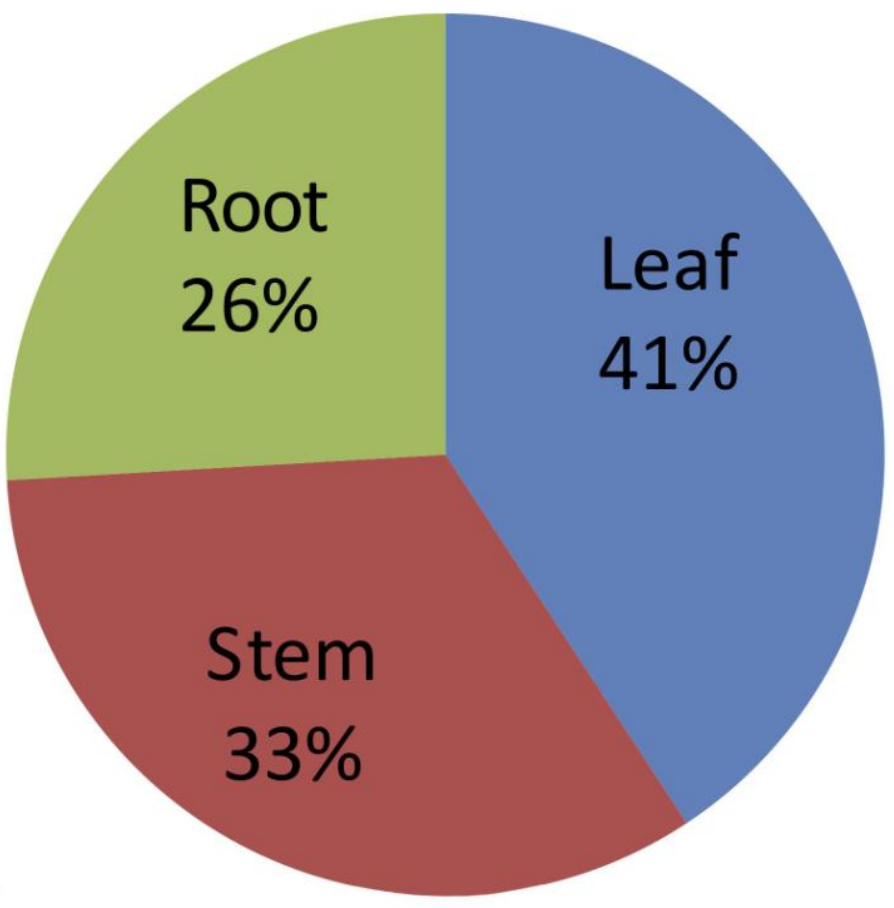


Fig.5 Colonizing frequency (\%) of endophytic fungi isolated from S. paniculate

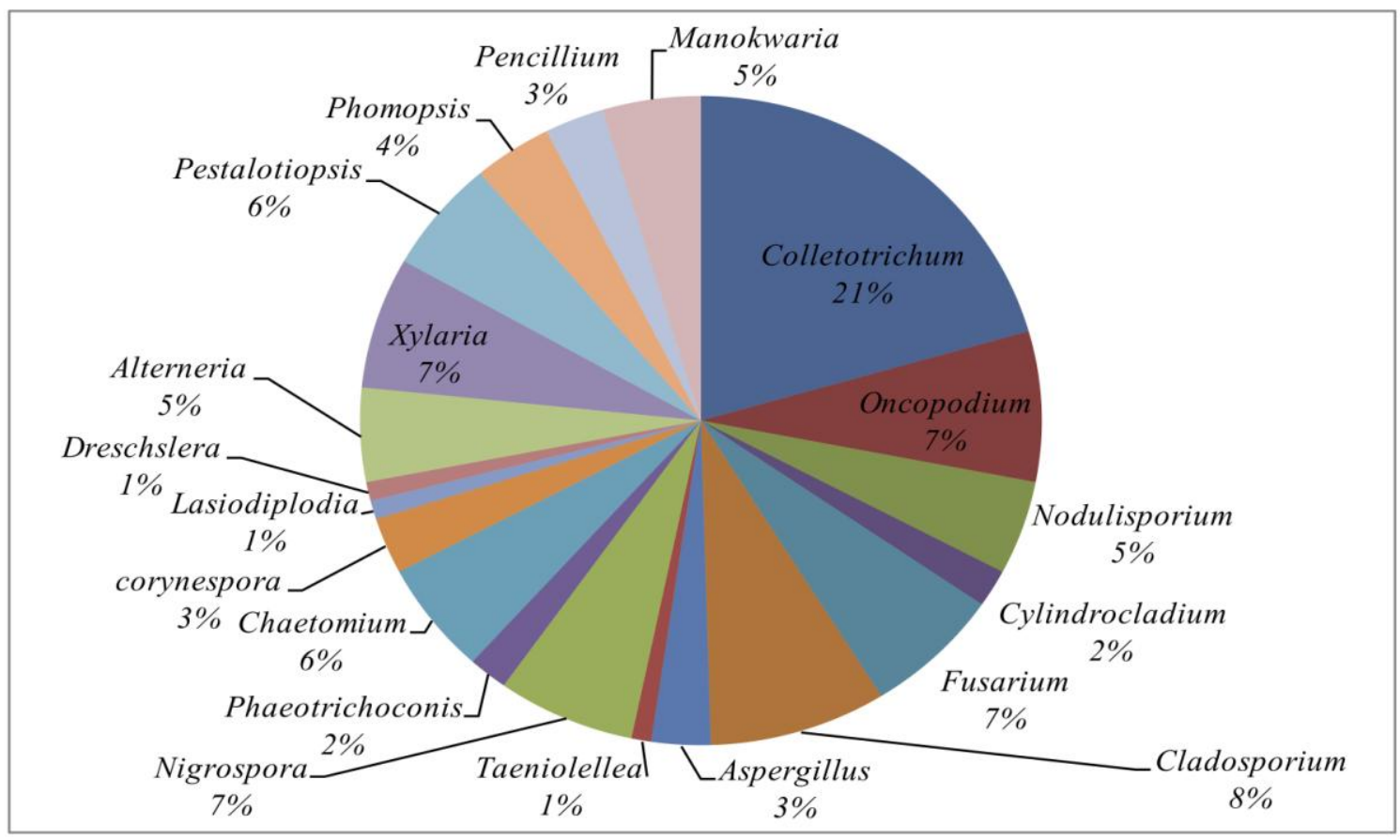

In the present study, among the endophytic fungal population, Colletotrichum sp. was found to be the most dominant endophytic species. Previously, this fungus was reported as a common endophyte to other plant species like Triticum aestivum, Zea mays (Zhang et al., 2006; Larran et al., 2002; Fisher et al., 1992). Colletotrichum sp. in Spaniculata was not organ-specific as the fungus was isolated from stems, leaves and roots. But frequency of colonization was higher in the leaves as compared to stem. There is sufficient evidence that endophytic fungi play an important role in host-plant physiology. They receive nutrition, protection and propagation opportunities from their hosts (Kenneth et al., 1965; Thrower and Lewis, 1973) while host plants are also benefited from this symbiosis. Endophytes provide protection to their hosts from insects, pests, and herbivore, and help their hosts to adapt in different stress conditions (Kenneth $e t$ al., 1965; Knop et al., 2007; Malinowski and Belesky, 2006; Clay et al., 2005). However, endophytes also act as opportunistic microorganisms under some conditions
(Saikkonen et al., 1998; Faeth et al., 2004).

A good amount of endophytic fungi were collected from this region. Colletotrichum was found to be the most dominant endophytic species followed by Fusarium, Manokwaria and Oncopodium. It is worth mentioning that the genera Pestalotiopsis, Drecheslra, Cylindrocladium, Aspergillus and Nodulisporium were, first reported from Arunachal Pradesh. The present study was therefore, a humble initiative to explore the potential fungal endophytic population in medicinal plant, that would pave a way for future research opportunities in this sector.

\section{Acknowledgements}

Authors are thankful to Department of Science and Technology, New Delhi, India for financing the study (SR/WOS-A/LS-170/2016); and Arunachal Pradesh Biodiversity Board, Government of Arunachal Pradesh for the scientific collection permit. 


\section{References}

Arnold A.E. (2007). Understanding the diversity of foliar endophytic fungi: progress, challenges, and frontiers. Fungal Biology Reviews 21:51-66.

Arnold A.E., Mejıa L.C., Kyllo D., Rojas E.I., Maynard Z., Robbins N. and Herre E.A. (2003). Fungal endophytes limit pathogen damage in a tropical tree. PNAS 100: 15649-15654.

Arnold, A.E. and Engelbrecht, B.M.J. (2007). Fungal endophytes nearly double minimum leaf conductance in seedlings of a neotropical tree species. J. Trop. Ecol., 23: 369-372.

Bacon, C.W. and J.F. White. (2000). An overview of endophytic microbes: Endophytism in ethnofisheries. Indian Journal Traditional Knowledge (4) 57-64.

Chowdhery, H.J. (1999). Floristic diversity and conservation strategies in India, Botanical

Clay, K. and Schardl, C. (2002). Evolutionary origins and ecological consequences of Endophyte symbiosis with grasses. Am. Nat., 160: S99-S127.

Clay, K., Fuqa, C., Lively, C. and Wade, M.J. (2005). Microbial community ecology of tick borne human pathogens. In: Disease Ecology: Community Structure and Pathogen Dynamics, (Ed.): S.K. Collinge and C. Ray. Oxford University Press, Oxford, pp. 41-57.

Dayle E.S., Polans, N.O., Paul, D.S. and Melvin, R.D. (2001). Angiosperm DNA contamination by endophytic fungi: Detection and methods of avoidance. Plant Molecular Biology Report, 19: 249260.

Domsch K.H., Gamas, W. and Anderson T.H. (1980). Compendium of Soil Fungi, Academic press, New York. Vol. 1: pp. 168-169, 540, 559-560.

Ellis M.B. (1971). Dematiaceous hypomycetes Common-wealth Mycology Institute, Kew, Surrey, England. pp. 319, 413-414, 465-466, 555-556.

Faeth, S.H., Helander, M.L. and Saikkonen, K.J.T. (2004). Asexual neotyphodium endophytes in a native grass reduce competitive abilities. Ecology Letters, 7: 304-313.

Fisher, P.J., Petrini, O. and Lappin-Scott, H.M. (1992). The distribution of some fungal and bacterial endophytes in maize (Zea mays L.). New Phytopathology, 122(2): 299-305.

Gangadevi, V. and Muthumary, J. (2007). Preliminary studies on cytotoxic effect of funga taxol on cancer cell lines. African Journal of Biotechnology, 6(12): 1382-86.

Kenneth B.R., Dorothy I.F. and Peter K.C.A. (1965). The genus Aspergillus. The Williams \& Wilkins Company, Baltimore. pp. 277-278; 408-411.

Khan, R. (2007). Isolation, identification and cultivation of endophytic fungi from medicinal plants for the production and characterization of bioactive Fungal Metabolites. PhD thesis, University of Karachi, Pakistan.

Khan, R., Shahzad, S., Choudhary. M., Khan, S.H. and Ahmad, A. (2010). Communities of endophytic fungi in medicinal plant Withania somnifera. Pakistan. J. Bot., 42: 1281-1287.

Knop, M., Pacyna, S., Voloshchuk, N., Kjant, S., Müllenborn, C., Steiner, U., Kirchmair, M., Scherer, H.W. and Schulz, M. (2007). Zea mays: Benzoxalinone Detoxification under sulfur deficiency conditions- A complex allelopathic alliance including endophytic Fusarium verticillioides. Journal of Chemical Ecology, 33(2): 225-237.

Krings M., Taylor T.N., Hass H., Kerp H., Dotzler N. and Hermsen E.J. (2007). Fungal endophytes in a 400-million-yrold land plant: infection pathways, spatial distribution, and host responses. New Phytologist 174: 648-657.

Larran, S., Rollán, C., Ángeles, H.B., Alippi, H.E. and Urrutia, M.I. (2002). Endophytic fungi in healthy soybean leaves. Invest. Agr. Prod. Prot. Veg., 17(1): 173-178.

Malinowski, D.P. and Belesky, D.P. (2006). Ecological importance of Neotyphodium spp. Grass endophytes in agroecosystems. 
Grassland Science, 52(1): 23-28.

Olson D.M. and Dinerstein E. (1998). The Global 200: A representation approach to conserving the Earth's most biologically valuable ecoregions. Conservation Biology 12: 502-515.

Owen N.L. and Hundley N. (2004). Endophytes - the chemical synthesizers inside plants. Science Progress 87:79-99.

Petrini, O. (1986). Taxonomy of endophytic fungi of aerial plant tissues. In: Microbiology of the phylosphere. (Ed.): N.J. Fokkenna, J. Van Den Heuvel. Cambridge University Press, Cambridge. pp. 175-187.

Redman R.S., Sheehan K.B., Stout R.G., Rodrigues R.J. and Henson J.M. (2002). Thermotolerance conferred to plant host and fungal endophyte during mutualistic symbiosis. Science 298: 1581.

Saikkonen, K., Faeth, S.H., Helander, M. and Sullivan, T.J. (1998). Fungal endophytes: a Continuum of interactions with host plants. Annual Review of Ecology and Systematics, 29: 319-343.

Selim K.A., El-Beih A.A., AbdEl-Rahman T.M. and El-Diwany A.I. (2012). Biology of endophytic fungi. Strobel, G.A. (2003). Endophytes as source of bioactive products. Microbiol. Infect. 5: 535-544.

Strobel, G.A., Hess, H.M., Frod, E., Sidhu, R.S. and Yang, X. (1996). Taxol from fungal endophytes and issue of biodiversity. Journal of industrial microbiology and biotechnology, 17(5-6): 417-423

Suryanarayanan, T.S., Govindarajulu, M.B. and Thirunavukkarasu, N. (2015). The need to explore the fungal facet of biodiversity of
Arunachal Pradesh. Journal of Bioresources 2(2): 9-17.

Suryanarayanan, T.S., Kumaresan, V. and Johnson J.A. (1998). Foliar fungal endophytes from two species of the mangrove Rhizophora. Canadian Journal of Microbiology 44:1003-1006.

Suryanarayanan, T.S., Venkatesan, G. and Murali T.S. (2003). Endophytic fungal communities in leaves of tropical forest trees: Diversity and distribution patterns. Current Science, 85(4): 489 - 492.

Sutton B.C. (1980). The Coelomycetes, Fungi Imperfecti with Pycnidia, Aceruli and Stromata. Robert Mac Lechose and Co. Ltd., University of Glasgow. England. pp. 82, 382, 385.

Tag H., Das A.K. and Kalita P. (2005). Plants used by the Hill Miri tribe of Arunachal Pradesh.

Tan R.X. and Zou W.X. (2001). Endophytes: a rich source of functional metabolites. Natural Product Reports 448-59.

Thrower, L.B. and Lewis, D.H. (1973). Uptake of sugars by Epichloë typhina (Pers. Ex Fr.) Tul. In culture and from its host, Agrostis stolonifera L. New Phytologist, 72: 501-508.

Weber J. (1981). A natural control of Dutch elm disease. Nature, London, 292: 449451.

Zhang H.W., Song Y.C. and Tan R.X. (2006). Biology and chemistry of endophytes. Nat. Pro. Rep., 23: 753-771.

Zhang, H.W., Y.C. Song, Y.C. and Tan, R.X. (2006). Biology and chemistry of endophytes. Nat. Prod. Rep., 23: 753-771.

\section{How to cite this article:}

Richa Sharma, Sumpam Tangjang and Tonlong Wangpan. 2018. First report on Biological Evaluation and Preliminary Screening of Fungal Endophytes from Spilanthes paniculata, a Medicinal Herb in Arunachal Pradesh, India. Int.J.Curr.Microbiol.App.Sci. 7(11): 1346-1354. doi: https://doi.org/10.20546/ijcmas.2018.711.157 